\title{
Assessing the ecological risk posed by a recently established invasive alien predator: Harmonia axyridis as a case study
}

Marc Kenis $^{1 *}$, Tim Adriaens ${ }^{2}$, Peter M.J. Brown ${ }^{3}$, Angelos Katsanis ${ }^{1,9}$, Gilles San Martin ${ }^{4}$, Etienne Branquart ${ }^{5}$, Dirk Maes ${ }^{2}$, René Eschen ${ }^{1}$, Renate Zindel ${ }^{1,6}$, Johan Van Vlaenderen ${ }^{1}$, Dirk Babendreier ${ }^{1}$, Helen E. Roy ${ }^{7}$, Louis Hautier ${ }^{4}$ and Remy L. Poland ${ }^{8}$

${ }^{1}$ CABI, 2800 Delémont, Switzerland

${ }^{2}$ Research Institute for Nature and Forest (INBO), 1070 Brussels, Belgium

${ }^{3}$ Animal \& Environment Research Group, Department of Life Sciences, Anglia Ruskin

University, Cambridge, CB1 1PT, UK

${ }^{4}$ Unité Protection des Plantes et Ecotoxicologie, Département Sciences du Vivant, Centre

Wallon de Recherches Agronomiques, B-5030 Gembloux, Belgium

${ }^{5}$ Invasive Species Unit, Département de l'Etude du Milieu Naturel et Agricole (DEMNA), Service Public de Wallonie, Avenue Maréchal Juin, 23 B-5030 Gembloux, Belgium

${ }^{6}$ Department of Biology, University of Fribourg, 1700 Fribourg, Switzerland

${ }^{7}$ NERC Centre for Ecology \& Hydrology, Crowmarsh Gifford, Oxfordshire, OX10 8BB, UK ${ }^{8}$ Clifton College, Clifton, Bristol, Avon, BS8 3JH, UK

${ }^{9}$ Present address: Department of Ecology and Evolutionary Biology, University of California Irvine, 92697-2525, CA, Irvine, USA

*Corresponding author:

Marc Kenis

CABI, 2800 Delémont, Switzerland

Tel: $+41(0) 324214884$

Fax: $+41(0) 324214871$

Email: m.kenis@cabi.org 
1 Which species are most at risk following the establishment of an 2 invasive predator: Harmonia axyridis as a case study 3 4 5 


\section{Abstract}

7 Invasive alien predators are a serious threat to biodiversity worldwide. However, there is no

8 generic method for assessing which local species are most at risk following the invasion of a

9 new predator. The harlequin ladybird, Harmonia axyridis (Pallas) (Coleoptera:

10 Coccinellidae), is an alien in Europe and many other parts of the world where it affects other

11 species of ladybirds through competition for food and intra-guild predation (IGP). Here, we

12 describe a method developed to assess which European ladybird species are most at risk

13 following the invasion of $H$. axyridis. The three components of the risk assessment are: the

14 likelihood that the assessed native species encounters $H$. axyridis in the field; the hazard of 15 competition for food; and the IGP hazard. Thirty native European ladybird species were 16 assessed through data obtained from field observations, laboratory experiments and literature 17 reviews. The species that are considered most at risk are found on deciduous trees, have 18 immature stages which are highly vulnerable to IGP by $H$. axyridis, and are primarily 19 aphidophagous. These species should be the focus of specific studies and possibly 20 conservation actions. The risk assessment method proposed here could be applied to other 21 alien predators which are considered a threat to native species through competition and 22 predation.

24 Keywords: Biological invasions; Coccinellidae; Ecological impact; Harmonia axyridis; Intraguild predation; Risk assessment 


\section{Introduction}

Invasive alien species are recognised as one of the main causes of animal biodiversity loss (Bellard et al. 2016). Associated animal species declines are mainly due to competitive exclusion, predation, and introduction of new diseases (Long 2003; Kenis et al. 2009). In particular, alien predatory insects are known to displace insects and other animals worldwide through competition for resources and predation (Snyder and Evans 2006; Wagner and Van Driesche 2010). In most cases, invasive alien insects have been introduced accidentally, either as contaminants or stowaways (Hulme et al. 2008). Nevertheless, predators and parasitoids have also been released intentionally in biological control programmes for pest control and a small proportion of them have had undesirable ecological effects on non-target species through competition for resources, predation or parasitism on native species (Hajek et al. 2016). Pre-release risk assessment protocols have the potential to limit the risk of non-target effects but these risk assessments are not yet carried out systematically in all countries (van Lenteren et al. 2006; Hajek et al. 2016). Other risk and impact assessment protocols exist for alien species beyond biological control introductions, many of which are appropriate for assessing predators (e.g. D'hondt et al. 2015; Kumschick et al. 2015) and some protocols have been developed for specific groups of predators, such as ants (Harris et al. 2005). However, these protocols aim at assessing the risk or impact of specific invasive alien species, taking into account their general impact in the invaded habitat (Kumschick and Richardson 2013). In contrast, there is no generic method to assess which particular native species are most at risk following the invasion of a predator. Such knowledge is usually lacking despite its obvious potential use for prioritising research and conservation actions in the invaded regions.

An example of an introduced arthropod predator that has had undesirable ecological impacts is the harlequin ladybird Harmonia axyridis (Pallas) (Coleoptera: Coccinellidae). This beetle was introduced into North America in 1916 and throughout the $20^{\text {th }}$ century to 
control aphids and coccids, and became established in the 1980s (Roy et al. 2016). Since then, although successfully regulating pest aphids in a range of crop systems, it has spread and increased in number rapidly across most of North America, where it has become the dominant aphidophagous ladybird (e.g. Colunga-Garcia and Gage 1998; Harmon et al. 2007). Harmonia axyridis was commercially available in Europe as a pest-control agent from the late 1980s and feral populations were first observed in Germany in 1999 (Brown et al. 2011). The beetle then rapidly invaded most European countries and many other regions on all continents except Antarctica (Roy et al. 2016).

The threat posed by $H$. axyridis to biodiversity and ecosystem functions in invaded regions may be considerable. Impacts on native species can occur both through direct predation and competition for resources. Harmonia axyridis has a broad diet, putting many non-target species at risk from predation. Whilst preferring aphid and coccid prey, $H$. axyridis will also accept the immature stages of many insects, including butterflies and other aphid predators (Koch et al. 2003; 2016; Pell et al. 2008). Intra-guild predation (IGP), i.e. the killing and eating of species eating similar, often limiting, resources (Polis et al. 1989) is widespread amongst aphidophagous insects, and $H$. axyridis is known to attack the immature stages of many ladybird guild members (Ware and Majerus 2008; Ware et al. 2008a; Katsanis et al. 2013; Rondoni et al. 2012a; 2012b). Recent observations have demonstrated that $H$. axyridis also feeds on European ladybirds in the field (Hautier et al. 2011; Thomas et al. 2013; Rondoni et al. 2014; Brown et al. 2015).

Negative effects of $H$. axyridis on native Coccinellidae have already been documented in North America. For example, H. axyridis was reported to be displacing Cycloneda sanguinea (L.), in Florida citrus orchards (Michaud 2002). Similarly, within four years of its arrival in Michigan, H. axyridis had taken over the status of Coleomegilla maculata (DeGeer) as the dominant aphid predator, and a decrease in populations of three other species of 
ladybird was reported: Brachiacantha ursina (F.), Cycloneda munda (Say) and Chilocorus stigma (Say) (Colunga-Garcia and Gage 1998). However, in an analysis of a 26-years dataset in the same region, Bahlai et al. (2015) confirmed the long term decline of two species only, C. maculata and Adalia bipunctata (L.).

In Europe, field studies have been undertaken in several countries to monitor changes in populations of native ladybird species following the arrival of $H$. axyridis (e.g. Eschen et al. 2007; Adriaens et al. 2008; Brown et al. 2011). A first assessment of the impact of $H$. axyridis on native species of ladybird in Belgium, Britain and Switzerland showed that some historically widespread and common species are declining (Roy et al. 2012). For $A$. bipunctata in Belgium, the rate of decline warrants red listing as a vulnerable species (Adriaens et al. 2015). However, ladybird populations are known to fluctuate naturally and, thus, it may take several years before a long-term impact can be ascertained. Also, some species were already in decline before the arrival of $H$. axyridis, suggesting that the invasion acted as an additional stressor on insect populations on top of other factors (Roy et al. 2012). Furthermore, general faunistic studies are able to monitor changes in the most abundant species but less common species are only rarely captured. It is essential that research is rapidly centred on those species that are most at risk and so we carried out a qualitative risk assessment for native ladybird species in Europe to determine those species that are most and least likely to decline following the invasion of $H$. axyridis. The risk was assessed for most “true ladybirds" (sensu Majerus 1994, i.e. sub-families Coccinellinae, Epilachninae and Chilocorinae) occurring in Western Europe.

This study also provides us with the opportunity to develop rapid and relevant methods of qualitative risk assessment for established alien predators. In particular, we hope that our approach may be usefully applied to other arthropod predators that are in the process of invasion and for which conclusive impacts on biodiversity are not yet observed or 
measurable. Also, for already established alien predators the results of such assessments can

104 inform risk management and prioritisation in uninvaded regions.

106 Materials and methods

107 A risk assessment involves identifying and quantifying the hazards, and determining the 108 probabilities that these hazards will materialise. The risk is then the product of a likelihood 109 (probability) and a magnitude of hazard (consequence). In this study, the risk posed by $H$. 110 axyridis on 30 native ladybirds (see list in Table 1) was considered as the product of the

111 likelihood that a given ladybird species encounters $H$. axyridis in the field, and the 112 consequence of this encounter, through competition for food and direct predation. Therefore, 113 the risk assessment was carried out in three steps: (1) likelihood of encounter with $H$. axyridis 114 in the field; (2) competition for food; (3) intra-guild predation.

116 Likelihood of encounter with $H$. axyridis in the field

117 The likelihood that a native ladybird species encounters $H$. axyridis in the field was measured 118 using field data in Switzerland, Belgium and Britain. Datasets comprising field observations 119 were used to assess spatial and temporal co-occurrence between native species and $H$. 120 axyridis. Since the data in the three countries had not been collected for this particular 121 purpose, sampling and, subsequently, calculation methods differed among countries. In Switzerland, extensive surveys for ladybirds carried out from 2006 to 2009 in the

123 North-Western part of the country (Cantons Jura, Basel-Landschaft, Basel-Stadt and

124 Solothurn) were used to calculate an 'asymmetric habitat overlap index', defined as 'the 125 proportion of specimens of a given species collected at the same time and the same site as $H$. 126 axyridis". The habitat overlap is qualified as "asymmetric" because no ladybird has exactly 127 the same habitat as another and, thus, the proportion of specimens of a species X collected 
with $H$. axyridis will most likely be different from the proportion of $H$. axyridis collected with

129 species X. Surveys (and site locations) were carried out as described in Eschen et al. (2007) and Zindel (2008). Branches of conifers, broadleaved trees and shrubs were beaten over a tray

131 to collect adult ladybirds. Meadows and grasslands were sampled using a sweep net. Insects

132 collected at the same time on the same group of trees (maximum $50 \mathrm{~m}$ distance), the same 133 hedgerow (maximum $50 \mathrm{~m}$ long) or the same meadow were considered to co-occur. We used 134 data exclusively obtained from sites where $H$. axyridis was thought to be established, i.e. 135 where either few specimens had been found in the previous year, or high numbers of 136 specimens had been found in the year of observation, and data were collected at the same site 137 for a maximum of two years. Using data from areas where $H$. axyridis was not yet established 138 could have resulted in false negative co-occurrence while using data from sites where $H$. 139 axyridis had been abundant for more than two years would have the risk that the displacement 140 of native species had already occurred. For 16 native ladybird species, for which at least 20 141 specimens were collected, the asymmetric habitat overlap index was measured. A total of 1422,956 records of adult specimens were included in the analyses.

143 In Belgium and Britain extensive national surveys were carried out in various habitats 144 providing occurrence data for a larger number of species (adults and, to a lesser extent, larvae) 145 but at lower resolution than in Switzerland (Adriaens et al. 2008; Brown et al. 2011; Roy et al. 146 2012). In Belgium, an index named "spatio-temporal co-occurrence with $H$. axyridis" was 147 calculated by Adriaens et al. (2008), based on occurrence data from 2004-2006 extracted from 148 the large dataset of the Belgian ladybird working group (Adriaens et al. 2012). It was defined 149 as the number of collection events (for which the following information was available: species 150 observed, number of individuals, development stage, observation date, observer and location) 151 where a given species had been found with $H$. axyridis, at the same date in a $1-\mathrm{km}^{2}$ grid cell, 152 divided by the total number of collection events with this species and any other ladybird 
153 species, including $H$. axyridis ( $\mathrm{n}=2,699$ collection events and over 10,000 individuals). This

154 index was calculated for all native ladybirds selected for the assessment. All species had over 15520 records in the database.

The British data were analysed similarly to the Belgian data. Ladybird species spatio-

157 temporal co-occurrence data (i.e. where two or more species were recorded at a site on the

158 same date, whether or not one of them was $H$. axyridis) from 2004-2008 were analysed $(\mathrm{n}=$

1593,069 collection events comprising 8,755 species records). Only species with over 20 records

160 were included. The records were mostly from specific site surveys, rather than general $1-\mathrm{km}^{2}$

161 surveys: $66.2 \%$ of the surveys in which $H$. axyridis was one of the species were recorded at

$162100 \mathrm{~m}$ square resolution or higher. In order to reduce the potential bias caused by a small

163 number of sites being surveyed many times on different dates, a grid reference was excluded

164 from the dataset if the grid reference / date combination had more than 40 records. The British

165 spatio-temporal index was calculated by dividing the number of records where $H$. axyridis

166 was recorded with a certain species by the total number of records for that species with any

167 other ladybird, including $H$. axyridis.

168 The three national co-occurrence indices were then used to assess the likelihood of

169 encounter in three-point scales. Since sampling and calculation methods differed in the three

170 countries, the range of the indices differed. Therefore, for each country, the index range (i.e.

171 the range between the minimum and the maximum indexes) was divided into three sections of

172 equal length and scored as follows: for species with index values in the highest section, the

173 likelihood of encounter was considered very likely (score 3), for those in the mid section,

174 moderately likely (score 2) and for those in the lowest section, unlikely (score 1):

175 3: Encounter very likely: Swiss data: above 46.4\%, Belgian data: above $57.0 \%$, British data:

176 above $13.9 \%$ 

data: $8.7-13.9 \%$

179 1: Encounter unlikely: Swiss data: less than $23.3 \%$, Belgian data: less than $38.7 \%$, British 180 data: less than $8.7 \%$ For each species, a final score of likelihood of encounter was given, corresponding to

182 the average of the country scores, rounded to the nearest unit. Where only two countries

183 provided a score for a particular species and these scores differed by one unit, the highest 184 score was selected.

\section{Competition for food}

187 A three-point scale was adopted to assess the exposure to competition for food, progressing 188 from minimal hazard (1) to major hazard (3). The exact degree of competition for food at the 189 field-scale is extremely difficult to assess. Nevertheless, the most obvious determinant of 190 whether competition for food represents a problem is whether the diet utilised by a given 191 species is also utilised by $H$. axyridis. Harmonia axyridis is recognised as a primarily 192 aphidophagous species, but is able to feed on other insects (Hodek and Evans 2012). Thus,

193 aphidophagous species will be most exposed to competition for food with $H$. axyridis. 194 Competition for coccids, adelgids or other insects is a possibility but probably less likely than 195 competition for aphids. Finally, species utilising more unusual diets, such as mildew, pollen 196 and plants will be least exposed to competition for food. Data on dietary requirements of 197 European ladybirds was obtained from the literature (e.g. Majerus 1994; Roy et al. 2011; 198 Hodek and Evans 2012) and used to assign each species to one of the following score 199 categories:

200 3. Major hazard: feeds principally on aphids

201 2. Moderate hazard: feeds principally on other insects 
1. Minor hazard: feeds principally on non-insect food

The consequence of IGP between $H$. axyridis and native species was assessed through experimental data available for 14 out of the 30 native species. Defensive strategies against 207 IGP at a range of life stages were also considered. Methods and results are described in detail 208 in Ware et al. (2008a), Ware and Majerus (2008) and Katsanis et al. (2013). Similar studies 209 from Félix and Soares (2004), Nóia et al. (2008) and Rondoni et al. (2012a, 2012b) were also 210 included in the assessment for two native species not covered by the three previously cited 211 references, i.e. Coccinella undecimpunctata L. and Platynaspis luteorubra Goeze. To 212 summarise, Petri-dish tests were conducted to collect data on: the susceptibility of different 213 coccinellids at the egg stage to predation by first instar $H$. axyridis larvae; the susceptibility of coccinellids at the pre-pupal and pupal stage to predation by the last (fourth) instar H. axyridis larval stage; and the outcome of confrontation between $H$. axyridis and the larvae of native species at first or fourth instar larvae. In each case, single larvae were exposed to either single 217 eggs, single larvae, pupae or pre-pupae for a period of 24 or 48 hours, without the presence of 218 any other food source. The full range of tests was carried out with A. bipunctata, A. 219 decempunctata (L.), Anatis ocellata (L.), Calvia quatuordecimguttata (L.), Coccinella 220 septempunctata L., Harmonia quadripunctata Pontoppidan, and Propylea 221 quattuordecimpunctata (L.). Egg predation was not tested with Coccinella quinquepunctata 222 L. and predation on pre-pupae and pupae was not tested on Aphidecta obliterata (L.), Calvia 223 decemguttata (L.), Hippodamia variegata (Goeze) and Oenopia conglobata (L.). Data on 224 predation on fourth instar larvae on P. luteorubra were retrieved from Rondoni et al. (2012a, 225 2012b) whereas Félix and Soares (2004) and Nóia et al. (2008) provided tests on all 226 developmental stages. 
The work described above in effect addressed physical and chemical defence only. In

228 reality, a range of behavioural tactics may be employed to reduce the risk of predation, many 229 of which may be unnoticeable within the confines of a Petri-dish. Certain behavioural 230 strategies may provide effective immediate escape from the risk of IGP by $H$. axyridis, such 231 as high mobility of larvae compared to $H$. axyridis and dropping off the plants when a 232 predator approaches (Sato et al. 2005). Such defence strategies, when known from the 233 literature or from unpublished observations, were taken into account in the assessment of the 23414 tested species, as described below. Based on the above, species were assigned to hazard scores as follows:

3. Major hazard: Native species highly susceptible, i.e. asymmetric IGP in favour of $H$. axyridis observed in at least two life stages; and no asymmetric IGP in favour of the native species observed in any stage; and short-term behavioural avoidance unlikely (i.e. no obvious strategies documented or observed for this species).

2. Moderate hazard: Native species less susceptible, i.e. no asymmetric IGP in favour of the native species observed in any stage but asymmetric IGP in favour of $H$. axyridis not 242 observed in more than one life stage. Or, if IGP observed in more than one life stage, short243 term behavioural avoidance observed and/or described in the literature.

1. Minor hazard: Asymmetric IGP in favour of the native species observed in at least one life stage. i.e. physical or chemical defences present at all or some life stages.

246 The 18 species that were not tested were given a moderate hazard score (2).

\section{$248 \quad$ Final risk assessment}

249 A total risk index score was calculated for each of the 30 native species, by multiplying the score of the likelihood of encounter by the sum of the two hazard scores. Ladybirds reaching 
251 the maximum risk index of $18(3 \times(3+3))$ were considered at very high risk, and those with 252 scores of 12-15, 8-10 and 2-6 were considered at high, medium and low risk, respectively. 253 


\section{Results}

\section{Likelihood of encounter with $H$. axyridis in the field}

257 Scores for likelihood of encounter were generally consistent in the three countries, 258 particularly for those species with high scores (Table 1). The species with the highest co259 occurrence indices, i.e. those most likely to encounter $H$. axyridis in the field, were 260 aphidophagous species living principally on broadleaved trees, i.e. Adalia spp., Calvia spp. 261 and O. conglobata. For example, in Switzerland, $69.8 \%$ of the A. bipunctata adults were 262 collected together with at least one $H$. axyridis. The lowest indices and scores were obtained 263 by species living in grasses, in particular the pollen and fungus feeding Tytthaspis sedecimpunctata (L.) or the phytophagous Henosepilachna argus (Geoffroy) or Subcoccinella vigintiquatuorpunctata (L.) (Table 1). No specimen of these three species was collected with $H$. axyridis during our surveys in Switzerland. Aphidophagous species associated with conifers, such as $A$. obliterata and ubiquitous species such as $C$. septempunctata and $P$. quattuordecimpunctata scored low, particularly in Switzerland, where only 3.4, 2.3 and $20.5 \%$ of the adults of these three species were collected with $H$. axyridis, respectively. In Britain and Belgium, $H$. axyridis co-occurred to a moderate extent with $C$. septempunctata,

271 especially where nettles (Urtica spp.) were prominent. Also, overall there was a moderately 272 high co-occurrence in Britain and Belgium with conifer specialists such as H. quadripunctata, 273 A. ocellata and Myrrha octodecimguttata (L.). Another conifer species, Myzia oblongoguttata 274 (L.) even scored high in Britain although H. axyridis is not abundant on pine trees in at least 275 parts of England (Brown et al. 2011).

\section{Competition for food}

278 From the 30 species included in the assessment, 19 are principally aphidophagous and were scored 3 to indicate the high potential for competition for food (Table 2). Chilocorinae 
(Chilocorus spp. and Exochomus spp.) feed mainly on scale insects. Aphidecta obliterata is

281 mainly a predator of Adelgidae and Coccinella hieroglyphica L. feeds mainly on

282 Chrysomelidae. They received a score of 2. Finally, three phytophagous species (Cynegetis

283 impunctata (L.), H. argus and S. vigintiquatuorpunctata) and three mostly mycophagous

284 species (Halyzia sedecimguttata (L.), Psyllobora vigintiduopunctata (L.) and $T$. 285 sedecimpunctata) were scored 1.

$\underline{\text { Intra-guild predation (IGP) }}$

Results of IGP tests are described in detail in previous publications (Félix and Soares 2004;

Ware and Majerus 2008; Ware et al. 2008a; Rondoni et al. 2012a, 2012b; Katsanis et al. 2013). From the 14 species in which IGP with $H$. axyridis was assessed, nine were highly vulnerable to IGP by $H$. axyridis and behavioural avoidance is not known. Thus these received a score of 3 (Table 2). Two of the tested species were scored 1. Eggs of $C$. quatuordecimguttata were avoided by $H$. axyridis larvae due to an external chemical deterrent (Ware et al. 2008b; Katsanis et al. 2013). Larvae of C. quatuordecimguttata were also less vulnerable to IGP than the other species tested and showed mostly symmetric IGP with $H$. axyridis larvae. Anatis ocellata larvae acted as the only asymmetric intra-guild predator of $H$. axyridis larvae (Katsanis et al. 2013). These results are attributed to differences in physical defensive structures: larvae of $H$. axyridis, $A$. ocellata and, to a lesser extent, $C$. quatuordecimguttata are protected by a covering of thick dorsal and dorsolateral spines, 300 whereas larvae of other species possess fine hairs only, or are sometimes almost smooth 301 (Ware and Majerus 2008; Roy et al. 2011). The only exception was H. quadripunctata, which 302 has spiny larvae similar to those of $H$. axyridis but was asymmetrically vulnerable to $H$. axyridis in the fourth instar and pre-pupal stages (Ware and Majerus 2008). Three species

304 that are also vulnerable to IGP by $H$. axyridis in Petri-dishes were nevertheless given a score 
of 2. Propylea quattuordecimpunctata larvae are noticeably long-legged and mobile and are,

306 therefore, more able to escape attack in the field (R. Poland, unpublished data). In addition,

307 larvae of $C$. septempunctata are commonly reported to drop from a host plant if a potential 308 predator approaches (Sato et al. 2005; Raak-van den Berg et al. 2012). Platynaspis luteorubra 309 was tested only in the fourth instar, by Rondoni et al. (2012a, 2012b). Although the IGP was 310 asymmetric in favour of $H$. axyridis, they noticed that $P$. luteorubra was not very susceptible 311 to attack by $H$. axyridis, which exhibited lower rates of successful attack and predation on $P$. 312 luteorubra than, e.g., A. bipunctata.

\section{$314 \quad$ Final risk assessment}

315 Four species, A. bipunctata, A. decempunctata, C. decemguttata and O. conglobata achieved 316 the maximum possible risk score of 18. Myzia oblongoguttata was scored 15 and $C$. quinquepunctata, $C$. undecimpunctata and $H$. quadripunctata were given a score of 12 . These four species are therefore also considered as being at relatively high risk. Eleven species achieved a score of 8-10, suggesting a moderate risk, and 11 species reached a low risk score of 2-6 (Table 3).

\section{Discussion}

323 The risk assessment method presented here allows us to rank European coccinellids according 324 to their order of risk from negative interactions with $H$. axyridis, thus informing the direction and focus of conservation and control initiatives. The four species identified as being most at risk, A. bipunctata, A. decempunctata, $C$. decemguttata and $O$. conglobata, are usually found

327 on deciduous trees, where $H$. axyridis is also found most commonly. They are primarily 328 aphidophagous and have immature stages which are highly vulnerable to IGP by $H$. axyridis. 329 Calvia quatuordecimguttata is another aphidophagous species living on broadleaved trees, 
and, thus, is likely to encounter and compete with $H$. axyridis in the field. However, in

331 contrast to other European species, its eggs are protected by a chemical deterrent and its 332 larvae are protected by strong spines, lowering the risk of displacement by $H$. axyridis (Ware 333 et al. 2008b; Katsanis et al. 2013; Katsanis et al. 2016).

Phytophagous and mycophagous ladybird species are clearly at lower risk because they do not compete for the same resource and will be less likely to encounter $H$. axyridis than homopteran-feeding ladybirds. Aphidophagous species found mainly or exclusively on conifers and in grasslands seem to be at medium risk. Harmonia axyridis shows a strong preference for broadleaved habitats compared to conifers and grasslands, as shown by our asymmetric habitat overlap index calculated in Switzerland. However, observations from

340 Belgium show that it can also be a dominant species on conifers (Adriaens et al. 2008). It is 341 also very abundant within herbaceous crops (e.g. Colunga-Garcia and Gage 1998; Jansen and Hautier 2008) but surveys in Switzerland and Britain showed that, more than ten years after

343 its arrival, it is still an uncommon species in grasslands, except when specific plants, such as 344 nettles, are present (Roy et al. 2011; M. Kenis, unpublished data). Among the three risk components considered in the method, the assessment of the 346 likelihood of encounter is a key element, albeit difficult to assess, particularly for uncommon species. We were fortunate that data from ladybird surveys were available from three countries over a relevant time period. However, these surveys were not carried out specifically for the purpose of risk assessment and, therefore, the data are not ideal for assessing habitat overlap. In particular, data from Belgium and, to a lesser extent, Britain, are 351 available at relatively low spatial resolution, which may still contain different habitats, such as 352 broadleaved trees and conifers or grasslands. Because of this scale issue, the likelihood of 353 encounter of a species with $H$. axyridis could be over-estimated. However, the results are 354 relatively consistent with a previous study showing high niche similarity between $H$. axyridis 
and these species at lower spatial scale i.e. based on co-occurrence on the same plants

356 (Adriaens et al. 2008). The common generalist species $C$. septempunctata appears to be stable 357 in distribution and abundance across Europe, despite the arrival of $H$. axyridis (Roy et al. 358 2012). The defensive behavioural strategy of its larvae may partly explain this. However, this species is mainly associated with herbaceous vegetation and low-scale spatio-temporal co-

360 occurrence indices may overestimate the likelihood of encounter with $H$. axyridis. Swiss 361 records were made at a higher spatial resolution i.e. a specific meadow, a broadleaved hedge 362 or a group of trees of a single conifer species. However, the Swiss dataset is smaller than the datasets from the two other countries and so less species could be properly assessed for their co-occurrence with $H$. axyridis. For example, C. quinquepunctata and $C$. undecimpunctata, found mainly on low vegetation, were not present in the Swiss dataset and it is possible that, 366 for these two species, the likelihood of encounter based on the Belgian and British dataset (2) and, consequently, the final risk scores (15) were overestimated. Furthermore, all records in Switzerland and most of them in Britain and Belgium were of adult ladybirds, while cooccurrence of larvae would be especially relevant since immature life stages are more susceptible to IGP and competition for food than adults, which are more mobile (Pell et al. 371 2008). However, for a given ladybird species, the adults and larvae use the same feeding resources and tend to frequently co-occur (e.g. Brown et al. 2011). It could be argued that the

373 likelihood of encounter could be derived from general habitat preference data gathered from 374 the literature. However, such data are too vague for most native coccinellid species, and often 375 inconsistent between information sources and geographic areas. Effects of direct interactions and defensive mechanisms are straightforward to assess 377 but the rearing of high numbers of ladybird species is time-consuming and some species are 378 difficult to rear due to their specific diets. Therefore, these effects could only be assessed by 379 the authors for 12 species and retrieved from other publications for two additional species. For 
380 the remaining 16 species, putative predation scores could be derived from defence 381 mechanisms of taxonomically or morphologically related species. However, without specific 382 IGP experiments, it would have been impossible to observe, e.g., that $C$. quatuordecimguttata eggs are chemically protected against predation while eggs of the closely-related $C$. decemguttata are not (Katsanis et al. 2016). Large larval spines, such as those of $H$. axyridis, A. ocellata and C. quatuordecimguttata seem to provide effective mechanical defence against 386 IGP (Katsanis et al. 2013). However, other spiny larvae such as those of H. quadripunctata 387 are vulnerable to $H$. axyridis predation (Ware and Majerus 2008). Furthermore, unpublished observations (A. Katsanis) showed that $H$. axyridis larvae are able to avoid spiny larvae of Exochomus quadripustulatus (L.) by biting them at their softer ventral surface. Other experiments, using $H$. axyridis larvae in which spines had been removed by hand, showed that 391 spines of $H$. axyridis allow reducing the bites from $C$. septempunctata but do not increase 392 survival, suggesting that spines are not the major component of its defence (Hautier 2012).

393 For these reasons, all non-tested species were given a medium predation score of 2 until 394 proper experiments are made. It must be noted that, even if the non-tested species had been scored high (3) in IGP tests, only one of them, M. oblongoguttata, would present a final risk 396 that is as high as that of the top four species because all the others showed a lower likelihood 397 of encounter. It could also be argued that observation of IGP in a Petri-dish does not necessarily translate to occurrence in the field. Analyses of exogenous alkaloids or DNA in 399 field-collected $H$. axyridis provide useful tools but will generally identify the most common 400 species (Hautier et al. 2011; Thomas et al. 2013; Rondoni et al. 2014; Brown et al. 2015). 401 Furthermore, the abundance of the extraguild prey (e.g. aphids) may affect IGP (Nóia et al. 402 2008). Thus, when possible, extraguild prey should be included in IGP tests. 
encounter, which depends on resource similarity, since eggs are laid close to resources

406 (Majerus 1994). One way to improve the assessment would be to consider the ladybird diet 407 more precisely, i.e. to prey species or genus level, but this requires a precise knowledge of 408 ladybird diets and preferences, which, for the moment, is largely lacking (Hodek and Evans 2012). Competitive interaction studies on competition for food between $H$. axyridis and

410 European ladybirds are rare. Soares and Serpa (2007) showed that the presence of H. axyridis

411 adults significantly affected the reproductive capacity of $C$. undecimpunctata even when the resource was not in short supply.

It remains to be seen whether long-term studies on ladybird species abundance that are

414 presently being carried out in the three countries will validate our risk assessments. The 415 Holarctic A. bipunctata, one of the species identified as most at risk in this study, has declined 416 severely in the last 20 years in North America, possibly due to the invasion of $H$. axyridis and other exotic ladybirds (Harmon et al. 2007; Bahlai et al. 2015). Strong evidence of a decline of $A$. bipunctata and, to a lesser extent, other native species has been demonstrated in Britain, Belgium and Switzerland (Brown et al. 2011; Roy et al. 2012; Comont et al. 2014; Adriaens et al. 2015). In Belgium and Britain, H. axyridis has been shown to commonly feed on Adalia spp. in the field (Hautier et al. 2011; Thomas et al. 2013; Rondoni et al. 2014; Brown et al. 2015). Interestingly, A. bipunctata, the species that shows by far the strongest decline in Europe, is also the one that showed the highest likelihood of encounter with H. axyridis in our 424 study, in particular in Switzerland where records were made at the highest spatial resolution. Had we based this assessment solely on the literature, we would probably have considered the congeneric $A$. decempunctata as having a higher likelihood of encountering $H$. axyridis than A. bipunctata because of its strong association with arboreal, broadleaved habitats. However, general long-term surveys, while suitable for assessing trends in abundant species, are less appropriate for detecting effects on rare species, which were sparsely recorded prior 
to the arrival of the invasive alien species. Therefore, it is essential that specific studies are

431 conducted focusing on species found historically at lower abundance and which were also 432 ascribed high scores in our risk assessment (such as $C$. decemguttata, O. conglobata and $C$. 433 quinquepunctata). The relative scarcity of these species coupled with their restricted 434 ecological niches could enhance the risk of local extinction.

Many generic assessment methods exist to assess the broad risk of invasive species, including predators, introduced accidentally or as biological control agents (e.g. van Lenteren et al. 2006; D'hondt et al. 2015; Kumschick et al. 2015). Other, more specific risk assessments focus on the hazard of predation on a single prey (e.g. Koch et al. 2006). rank a whole set of native species, according to their order of risk from negative interactions with the invasive species. It is hoped that the risk assessment method proposed here could be applied to other situations where the arrival of an alien predator potentially threatens native species through competition and intra-guild or extra-guild predation. Classifying competitor or prey species according to their exposure and vulnerability, and selecting the most vulnerable species for research, protection and conservation programmes could be a useful approach. Potential candidates include, among others, several invasive alien predatory wasps and hornets that threaten biodiversity worldwide. For example, the Asian hornet, Vespa velutina, a recent invader in Western Europe, may displace various native insects such as

449 bees, flies and vespid wasps through direct predation and competition (Beggs et al. 2011). The 450 same approach could also be considered for assessing the risk of invasive ants since these are 451 also generalist predators that are known to threaten native species, in particular ants, through 452 various mechanisms (Holway et al. 2002). Furthermore, this approach is not limited to insects. 453 Other predatory terrestrial and aquatic invertebrates would be suitable for similar assessments. 454 For example, the killer shrimp, Dikerogammarus villosus, has undergone an explosive 
455 invasion in Europe in the last two decades and has recently been found in Britain (MacNeil et 456 al. 2010), where a similar risk assessment could be performed to evaluate which native 457 gammarids or other aquatic invertebrates are most at risk. A similar protocol could be 458 developed for invasive alien predaceous fish, amphibians, reptiles and even mammals, with 459 some taxon-specific adaptations. The approach is primarily applicable to assess the risk posed 460 to the displacement of native biodiversity by an invasive alien predator that is at an early stage 461 of invasion, for which a firm impact cannot yet be ascertained but habitat and food overlaps 462 can already be calculated. The approach should be used with more caution for risk assessments prior to invasion, but could for example complement pre-release risk assessment 464 protocols for biological control agents (van Lenteren et al. 2006; Hajek et al. 2016), in which 465 case a likelihood of encounter score could be estimated based on parameters such as general 466 habitat requirements or feeding niches defined from data collected in the present distribution range of the species.

\section{References}

470 Adriaens T, San Martin y Gomez G, Maes D (2008) Invasion history, habitat preferences and 471 phenology of the invasive ladybird Harmonia axyridis in Belgium. BioControl 53:69-88

472 Adriaens T, San Martin y Gomez G, Maes D, Brosens D, Desmet P (2012) Belgian 473 Coccinellidae - Ladybird beetles in Belgium. v1.0. Research Institute for Nature and Forest 474 (INBO). Dataset/Occurrence. http://doi.org/10.15468/0refva. Cited 15 March 2016

475 Adriaens T, San Martin y Gomez G, Bogaert J, Crevecoeur L, Beuckx J-P, Maes D (2015) 476 Testing the applicability of regional IUCN Red List criteria on ladybirds (Coleoptera, 477 Coccinellidae) in Flanders (north Belgium): opportunities for Conservation. Insect Conserv 478 Divers 8:404-417 
Bahlai CA, Colunga-Garcia M, Gage SH, Landis DA (2015) The role of exotic ladybeetles in the decline of native ladybeetle populations: evidence from long-term monitoring. Biol Invasions 17:1005-1024

Beggs JR, Brockerhoff EG, Corley JC, Kenis M, Masciocchi M, Muller F, Rome Q, Villemant C (2011) Ecological effects and management of invasive alien Vespidae. BioControl 56:505-526

Bellard C, Cassey P, Blackburn TM (2016) Alien species as a driver of recent extinctions. Biol Lett. doi: 10.1098/rsbl.2015.0623

Brown PMJ, Frost R, Dobersk, J, Sparks T, Harrington R, Roy HE (2011) Decline in native ladybirds in response to the arrival of Harmonia axyridis: Early evidence from England. Ecol Entomol 36:231-240

Brown PMJ, Ingels B, Wheatley A, Rhule EL, de Clercq P, van Leeuwen T, Thomas A (2015) Intraguild predation by Harmonia axyridis (Coleoptera: Coccinellidae) on native insects in Europe: molecular detection from field samples. Entomol Scie 18:130-133

Colunga-Garcia M, Gage SH (1998) Arrival, establishment, and habitat use of the multicolored Asian lady beetle (Coleoptera: Coccinellidae) in a Michigan landscape. Environ Entomol 27:1574-1580

Comont RF, Roy HE, Harrington R, Shortall CR, Purse BV (2014). Ecological correlates of local extinction and colonisation in the British ladybird beetles (Coleoptera: Coccinellidae). Biol Invasions 16:1805-1817

D'hondt B, Vanderhoeven S, Roelandt S, Mayer F, Versteirt V, Adriaens T, Ducheyne E, San Martin G, Grégoire JC, Stiers I, Quoilin S, Cigar J, Heughebaert A, Branquart E (2015) Harmonia+ and Pandora+: risk screening tools for potentially invasive plants, animals and their pathogens. Biol Invasions 17:1869-1883 
Eschen R, Babendreier D, Nauer S, Bigler F, Kenis M (2007) Surveys for ladybirds

504 (Coleoptera: Coccinellidae) in Switzerland and confirmation of the presence of the invasive alien ladybird species Harmonia axyridis (Pallas). Mitt Schweiz Entomol Ges 80: $7-14$

Félix S, Soares AO (2004) Intraguild predation between the aphidophagous ladybird beetles Harmonia axyridis and Coccinella undecimpunctata (Coleoptera: Coccinellidae): the role of body weight. Eur J Entomol 101: 237-242

Hajek AE, Hurley BP, Kenis M, Garnas JR, Bush SJ, Wingfield MJ, van Lenteren JC, Cock MJ (2016) Exotic biological control agents: a solution or contribution to arthropod invasions? Biol Invasions. doi: 10.1007/s10530-016-1075-8

Harmon JP, Stephens E, Losey J (2007) The decline of native coccinellids (Coleoptera: Coccinellidae) in the United States and Canada. J Insect Conserv 11:85-94

Harris R, Abbott K, Barton K, Berry J, Don W, Gunawardana D, Lester P, Rees J, Stanley M, Sutherland A, Toft R (2005) Invasive ant pest risk assessment project for Biosecurity New Zealand. Series of unpublished Landcare Research contract reports to Biosecurity New Zealand. BAH/35/2004-1

519 Hautier L (2012) Intraguild predation in Harmonia axyridis and its effects on native 520 coccinellids. PhD thesis, Université Libre de Bruxelles, Belgium

521 Hautier L, San Martin y Gomez G, Callier P, de Biseau J, Gregoire J (2011) Alkaloids 522 provide evidence of intraguild predation on native coccinellids by Harmonia axyridis in 523 the field. Biol Invasions 13:1805-1814

524 Hodek I, Evans EW (2012) Food relationships. In: Hodek I, van Emden HF, Honek A (eds) 525 Ecology and behaviour of the ladybird beetles (Coccinellidae), Wiley-Blackwell, 526 Chichester 
Hodek I, van Emden HF, Honek A (eds) (20129 Ecology and behaviour of the ladybird beetles (Coccinellidae), Wiley-Blackwell, Chichester

Holway DA, Lach L, Suarez A, Tsutsui N, Case TJ (2002) The causes and consequences of ant invasions. Annu Rev Ecol Syst 33:181-233

Hulme P, Bacher S, Kenis M, Klotz S, Kuhn I, Minchin D, Nentwig W, Olenin S, Panov V, Pergl J, Pysek P, Roques A, Sol D, Solarz W, Vila M (2008) Grasping at the routes of biological invasions: a framework for integrating pathways into policy. $\mathrm{J}$ Appl Ecol $45: 403-414$

Jansen J-P, Hautier L (2008) Ladybird population dynamics in potato: Comparison of native species with an invasive species, Harmonia axyridis. Biocontrol 53: 223-234

Katsanis A, Babendreier D, Nentwig W, Kenis M (2013) Intraguild predation between the invasive ladybird Harmonia axyridis and non-target European coccinellid species. BioControl 58:73-83

Katsanis A, Magro A, Ramon-Portugal F, Kenis M, Babendreier D (2016) Chemical defences of native European coccinellid eggs against intraguild predation by the invasive Asian coccinellid, Harmonia axyridis (Pallas). BioControl, this issue

Kenis M, Auger-Rozenberg M-A, Roques A, Timms L, Péré C, Cock MJW, Settele J, Augustin S, Lopez-Vaamonde C (2009) Ecological effects of invasive alien insects. Biol Invasions 11:21-45

546 Koch RL, Hutchison WD, Venette RC, Heimpel GE (2003) Susceptibility of immature monarch butterfly, Danaus plexippus (Lepidoptera: Nymphalidae: Danainae), to predation by Harmonia axyridis (Coleoptera: Coccinellidae). Biol Control 28:265-270 predator on monarch butterfly (Lepidoptera: Nymphalidae) populations: a quantitative risk 
552 Kumschick S, Richardson DM (2013) Species-based risk assessments for biological 553 invasions: Advances and challenges. Divers Distrib 19:1095-1105

554 Kumschick S, Bacher S, Marková Z, Pergl J, Pyšek P, Vaes-Petignat S, van der Veer G, Vilà 555 M, Nentwig W (2015) Comparing impacts of alien plants and animals using a standard $556 \quad$ scoring system. J Appl Ecol 52: 552-561

557 Long JL (2003) Introduced mammals of the world. Their history distribution and influence. $558 \quad$ CABI, Wallingford

559 MacNeil C, Plavoet D, Dick JTA, Fielding N, Constable A, Hall N, Aldridge D, Renals T, 560 Diamond M (2010) The Ponto-Caspian 'killer shrimp', Dikerogammarus villosus 561 (Sowinsky, 1894), invades the British Isles. Aquat Invasions 5:441-445

562 Majerus MEN (1994) Ladybirds (No. 81, New Naturalist Series). HarperCollins, London.

563 Michaud JP (2002) Invasion of the Florida citrus ecosystem by Harmonia axyridis 564 (Coleoptera : Coccinellidae) and asymmetric competition with a native species, Cycloneda sanguinea. Environ Entomol 31:827-835

566 Nóia M, Borges I, Soares AO (2008) Intraguild predation between the aphidophagous 567 ladybird beetles Harmonia axyridis and Coccinella undecimpunctata (Coleoptera: 568 Coccinellidae): the role of intra and extraguild prey densities. Biol Control 46: 140-146.

569 Pell JK, Baverstock J, Roy HE, Ware RL, Majerus MEN (2008) Intraguild predation 570 involving Harmonia axyridis: a review of current knowledge and future perspectives. $571 \quad$ BioControl 53:147-168

572 Polis GA, Myers CA, Holt RD (1989) The ecology and evolution of intraguild predation: 573 potential competitors that eat each other. Annu Rev Ecol Syst 20:297-330

574 Raak-van den Berg CL, De Lange HJ, Van Lenteren JC (2012). Intraguild predation 575 behaviour of ladybirds in semi-field experiments explains invasion success of Harmonia $576 \quad$ axyridis. PloS one: 7: e40681. 
Rondoni G, Onofri A, Ricci C (2012a) Laboratory studies on intraguild predation and cannibalism among coccinellid larvae (Coleoptera: Coccinellidae). Eur J Entomol 109:353362

Rondoni G, Onofri A, Ricci C (2012b) Differential susceptibility in a specialised aphidophagous ladybird, Platynaspis luteorubra (Coleoptera: Coccinellidae), facing intraguild predation by exotic and native generalist predators. Biocontrol Sci Technol 22:1334-1350

Rondoni G, Athey KJ, Harwood JD, Conti E, Ricci C, Obrycki JJ (2014) Development and application of molecular gut-content analysis to detect aphid and coccinellid predation by Harmonia axyridis (Coleoptera: Coccinellidae) in Italy. Insect sci. doi:10.1111/17447917.12165

Roy HE, Brown PMJ, Frost R, Poland RL (2011) Ladybirds (Coccinellidae) of Britain and Ireland. NERC Centre for Ecology \& Hydrology, Wallingford

Roy HE, Adriaens T, Isaac NJB, Kenis M, Onkelinx T, San Martin G, Brown PMJ, Hautier L, Poland R, Roy DB, Comont R, Eschen R, Frost R, Zindel R, Van Vlaenderen J, Nedvěd

Roy HE, Brown PMJ, Adriaens T, Berkvens N, Borges I, Clusella-Trullas S, De Clercq P, Comont RF, Eschen R, Estoup A, Evans EW, Facon B, Gardiner MM, Gil A, Grez AA, AO, Maes D, Magro A, Murray KM, San Martin G, Martinkova Z, Minnaar IA, Nedved O, Orlova-Bienkowskaja MJ, Rabitsch W, Ravn HP, Rondoni G, Rorke SL, Ryndevich SK, Saethre M-G, Sloggett JJ, Soares AO, Stals R, Tinsley MC, Vandereycken A, van Wielink P, Viglášová S, Zach P, Zakharov IA, Zaviezo T, Zhao Z (2016) The harlequin ladybird, 
602 Harmonia axyridis: global perspectives on invasion history and ecology. Biol Invasions. 603 doi:10.1007/s10530-016-1077-6

604 Sato S, Yasuda H, Evans EW (2005) Dropping behaviour of larvae of aphidophagous 605 ladybirds and its effects on incidence of intraguild predation: interactions between the 606 intraguild prey, Adalia bipunctata (L.) and Coccinella septempunctata (L.), and the 607 intraguild predator, Harmonia axyridis Pallas. Ecol Entomol 30:220-224

608 Snyder WE, Evans EW (2006) Ecological effects of invasive arthropod generalist predators. 609 Annu Rev Ecol Evol Syst 37:95-122

610 Soares AO, Serpa A (2007) Interference competition between ladybird beetle adults 611 (Coleoptera: Coccinellidae): effects on the growth and reproductive capacity. Pop Ecol 49: $612 \quad 37-43$

613 Thomas A, Trotman J, Wheatley A, Aebi A, Zindel R, Brown PMJ (2013) Predation of native 614 coccinellids by the invasive alien Harmonia axyridis (Coleoptera: Coccinellidae): 615 detection in Britain by PCR based gut analysis. Insect Conserv Divers 6:20-27

616 van Lenteren JC, Bale JS, Bigler F, Hokkanen HMT, Loomans AJM (2006) Assessing risks 617 of releasing exotic biological control agents of arthropod pests. Annu Rev Entomol $618 \quad 51: 609-634$

619 Wagner D L, Van Driesche RG (2010) Threats posed to rare or endangered insects by 620 invasions of nonnative species. Annu Rev Entomol 55:547-568

621 Ware RL, Majerus MEN (2008) Intraguild predation of immature stages of British and 622 Japanese coccinellids by the invasive ladybird Harmonia axyridis. BioControl 53:169-188

623 Ware RL, Evans N, O'Farrell K, Majerus MEN, Malpas L, Michie LJ (2008a) Intraguild 624 predation of British and Japanese coccinellid eggs by the invasive ladybird Harmonia $625 \quad$ axyridis. Neobiota 7:263-275 
626 Ware RL, Ramon-Portugal F, Magro A, Ducamp C, Hemptinne J-L, Majerus MEN (2008b)

627 Chemical protection of Calvia quatuordecimguttata eggs against intraguild predation by 628 the invasive ladybird Harmonia axyridis. BioControl 53:189-200

629 Zindel R (2008) The potential impact of an exotic ladybird, Harmonia axyridis (Pallas), on 630 native species in Switzerland. Master Thesis, University of Fribourg, Switzerland 631 632 


\section{Acknowledgements}

The authors acknowledge the help and support of I. Wright and L-J. Michie, formerly of the Department of Genetics, University of Cambridge, UK. The work in Switzerland was supported by the EU project ALARM (GOCE-CT-2003-506675) and grants from the Swiss Federal Office for the Environment (F232-0377) and the Swiss National Science Foundation (3100A0-117831). HER is supported by the Natural Environment Research Council, Joint Nature Conservation Committee and the Department for the Environment, Food and Rural Affairs. We are very grateful to all the recorders contributing records to the national surveys in Britain and Belgium. 
Table 1 The 30 native coccinellid species for which the risk was assessed, main habitats, asymmetric habitat overlap index in Switzerland, spatio-temporal co-occurrence index in Belgium and Britain and final score of likelihood of encounter. Information from the main habitats was obtained from the literature on Coccinellidae (e.g. Adriaens et al. 2008; Majerus 1994; Roy et al. 2011; Hodek et al. 2012)

\begin{tabular}{|c|c|c|c|c|c|}
\hline \multirow[t]{2}{*}{ Species } & \multirow[t]{2}{*}{ Main habitats } & \multicolumn{3}{|c|}{ Index \% (score) } & \multirow{2}{*}{$\begin{array}{l}\text { Final } \\
\text { score }\end{array}$} \\
\hline & & Switzerland & Belgium & Britain & \\
\hline Adalia bipunctata (L.) & Various & $69.8(3)$ & $61.2(3)$ & $19.6(3)$ & 3 \\
\hline Adalia decempunctata (L.) & Deciduous trees & $53.1(3)$ & $63.8(3)$ & $15.1(3)$ & 3 \\
\hline Anatis ocellata (L.) & Coniferous trees & - & $50.8(2)$ & $13.4(2)$ & 2 \\
\hline Anisosticta novemdecimpunctata (L.) & Reed beds & - & $49.2(2)$ & $3.3(1)$ & 2 \\
\hline Aphidecta obliterata (L.) & Coniferous trees & $3.4(1)$ & $56.0(2)$ & $5.4(1)$ & 1 \\
\hline Calvia decemguttata (L.) & $\begin{array}{l}\text { Deciduous trees } \\
\text { and hedgerows }\end{array}$ & - & $67.7(3)$ & - & 3 \\
\hline Calvia quatuordecimguttata (L.) & Deciduous trees & $44.9(2)$ & $60.6(3)$ & $9.2(2)$ & 2 \\
\hline Chilocorus bipustulatus (L.) & $\begin{array}{l}\text { Heathland and } \\
\text { other habitats }\end{array}$ & $8.7(1)$ & $59.4(3)$ & $15.6(3)$ & 2 \\
\hline Chilocorus renipustulatus (Scriba) & Deciduous trees & $19.5(1)$ & $33.3(1)$ & $6.5(1)$ & 1 \\
\hline Coccinella hieroglyphica L. & Heathland & - & $20.3(1)$ & - & 1 \\
\hline Coccinella magnifica Redtenbacher & $\begin{array}{l}\text { Close to nests of } \\
\text { Formica ants }\end{array}$ & - & $48.1(2)$ & - & 2 \\
\hline Coccinella quinquepunctata $\mathrm{L}$. & $\begin{array}{l}\text { Pioneer low } \\
\text { vegetation }\end{array}$ & - & $49.2(2)$ & - & 2 \\
\hline Coccinella septempunctata $\mathrm{L}$. & Various & $2.3(1)$ & $53.3(2)$ & $11.3(2)$ & 2 \\
\hline Coccinella undecimpunctata $\mathrm{L}$. & Herbaceous plants & - & $46.3(2)$ & $12.8(2)$ & 2 \\
\hline Cynegetis impunctata (L.) & Wet grassland & - & $44.4(2)$ & - & 2 \\
\hline Coccinula quatuordecimpustulata L.) & Dry grassland & - & $48.8(2)$ & - & 2 \\
\hline Exochomus nigromaculatus (Goeze) & $\begin{array}{l}\text { Heathland and } \\
\text { other habitats }\end{array}$ & - & $40.4(2)$ & - & 2 \\
\hline Exochomus quadripustulatus (L.) & $\begin{array}{l}\text { Needled conifers, } \\
\text { deciduous trees }\end{array}$ & $23.9(2)$ & $57.3(3)$ & $10.9(2)$ & 2 \\
\hline Halyzia sedecimguttata (L.) & Deciduous trees & $31.4(2)$ & $56.5(2)$ & $18.5(3)$ & 2 \\
\hline Harmonia quadripunctata Pontoppidan & Needled conifers & $27.8(2)$ & $53.9(2)$ & $13.5(2)$ & 2 \\
\hline Henosepilachna argus (Geoffroy) & Low herbage & - & $27.3(1)$ & - & 1 \\
\hline $\begin{array}{l}\text { Hippodamia } \\
\text { variegata (Goeze) }\end{array}$ & $\begin{array}{l}\text { Reed beds, } \\
\text { meadowland }\end{array}$ & $4.2(1)$ & $46.5(2)$ & $4.3(1)$ & 1 \\
\hline Myrrha octodecimguttata (L.) & Coniferous trees & - & $45.2(2)$ & $12.1(2)$ & 2 \\
\hline Myzia oblongoguttata (L.) & Coniferous trees & - & $39.4(2)$ & $15.0(3)$ & 3 \\
\hline Oenopia conglobata $(\mathrm{L})$. & Deciduous trees & $66.7(3)$ & $75.5(3)$ & - & 3 \\
\hline Platynaspis luteorubra (Goeze) & $\begin{array}{l}\text { Association with } \\
\text { Lasius niger }\end{array}$ & - & $44.8(2)$ & - & 2 \\
\hline Propylea quattuordecimpunctata (L.) & Various & $20.5(1)$ & $52.2(2)$ & $7.9(1)$ & 1 \\
\hline Psyllobora vigintiduopunctata (L.) & Low vegetation & $20.3(1)$ & $55.6(2)$ & $7.7(1)$ & 1 \\
\hline $\begin{array}{l}\text { Subcoccinella vigintiquatuorpunctata } \\
\text { (L.) }\end{array}$ & Grassland & $0.0(1)$ & $35.8(1)$ & $5.6(1)$ & 1 \\
\hline Tytthaspis sedecimpunctata (L.) & Grassland, & $0.0(1)$ & $42.4(2)$ & $6.0(1)$ & 1 \\
\hline
\end{tabular}


Table 2 Dietary specialisation and effective defensive strategies against $H$. axyridis of the 30 European coccinellids assessed in the study and ascribed competition and predation scores. Information on principal food was obtained from the literature (e.g. Majerus 1994; Roy et al. 2011; Hodek and Evans 2012). For defensive strategies, see the text.

\begin{tabular}{|c|c|c|c|c|}
\hline Species & Principal food & $\begin{array}{c}\text { Competition } \\
\text { Score }\end{array}$ & Defensive strategies & Predation Score \\
\hline Adalia bipunctata & Aphids & 3 & None & 3 \\
\hline Adalia decempunctata & Aphids & 3 & None & 3 \\
\hline Anatis ocellata & Aphids & 3 & Physical & 1 \\
\hline $\begin{array}{l}\text { Anisosticta } \\
\text { novemdecimpunctata* }\end{array}$ & Aphids & 3 & Unknown & 2 \\
\hline Aphidecta obliterata & Adelgids & 2 & None & 3 \\
\hline Calvia decemguttata & Aphids & 3 & None & 3 \\
\hline $\begin{array}{l}\text { Calvia } \\
\text { quatuordecimguttata }\end{array}$ & Aphids & 3 & Physical, chemical & 1 \\
\hline Chilocorus bipustulatus* & Coccids & 2 & Unknown & 2 \\
\hline $\begin{array}{l}\text { Chilocorus } \\
\text { renipustulatus* }\end{array}$ & Coccids & 2 & Unknown & 2 \\
\hline $\begin{array}{l}\text { Coccinella } \\
\text { hieroglyphica* }\end{array}$ & $\begin{array}{l}\text { Chrysomelids, } \\
\text { aphids }\end{array}$ & 2 & Unknown & 2 \\
\hline Coccinella magnifica* & Aphids & 3 & Unknown & 2 \\
\hline $\begin{array}{l}\text { Coccinella } \\
\text { quinquepunctata }\end{array}$ & Aphids & 3 & None & 3 \\
\hline $\begin{array}{l}\text { Coccinella } \\
\text { septempunctata }\end{array}$ & Aphids & 3 & Behavioural & 2 \\
\hline $\begin{array}{l}\text { Coccinella } \\
\text { undecimpunctata }\end{array}$ & Aphids & 3 & None & 3 \\
\hline Cynegetis impunctata* & Plants & 1 & Unknown & 2 \\
\hline $\begin{array}{l}\text { Coccinula } \\
\text { quatuordecimpustulata* }\end{array}$ & Aphids & 3 & Unknown & 2 \\
\hline $\begin{array}{l}\text { Exochomus } \\
\text { nigromaculatus* }\end{array}$ & $\begin{array}{l}\text { Coccids, adelgids } \\
\text { and other woolly } \\
\text { aphids }\end{array}$ & 2 & Unknown & 2 \\
\hline $\begin{array}{l}\text { Exochomus } \\
\text { quadripustulatus* }\end{array}$ & Coccids & 2 & Unknown & 2 \\
\hline Halyzia sedecimguttata* & Mildew & 1 & Unknown & 2 \\
\hline $\begin{array}{l}\text { Harmonia } \\
\text { quadripunctata }\end{array}$ & Aphids & 3 & Physical & 3 \\
\hline Henosepilachna argus* & Plants & 1 & Unknown & 2 \\
\hline Hippodamia variegata & Aphids & 3 & None & 3 \\
\hline $\begin{array}{l}\text { Myrrha } \\
\text { octodecimguttata* }\end{array}$ & Aphids & 3 & Unknown & 2 \\
\hline Myzia oblongoguttata* & Aphids & 3 & Unknown & 2 \\
\hline Oenopia conglobata & Aphids & 3 & None & 3 \\
\hline Platynaspis luteorubra & Aphids & 3 & Poor & 2 \\
\hline $\begin{array}{l}\text { Propylea } \\
\text { quattuordecimpunctata }\end{array}$ & Aphids & 3 & Behavioural (running) & 2 \\
\hline $\begin{array}{l}\text { Psyllobora } \\
\text { vigintiduopunctata* }\end{array}$ & Mildew & 1 & Unknown & 2 \\
\hline $\begin{array}{l}\text { Subcoccinella } \\
\text { vigintiquatuorpunctata* }\end{array}$ & Plants & 1 & Unknown & 2 \\
\hline $\begin{array}{l}\text { Tytthaspis } \\
\text { sedecimpunctata* }\end{array}$ & $\begin{array}{l}\text { Pollen, mildew, } \\
\text { non-homopteran } \\
\text { arthropods }\end{array}$ & 1 & Unknown & 2 \\
\hline
\end{tabular}

*Species that were not experimentally assessed for the impact of intra-guild predation. 
Table 3 Final assessment of the risk posed to 30 European coccinellids by Harmonia axyridis. See text and Fig. 1 for description of risk categories and scoring method

\begin{tabular}{|c|c|c|c|c|}
\hline Species & $\begin{array}{l}\text { Likelihood } \\
\text { of encounter }\end{array}$ & $\begin{array}{c}\text { Competition } \\
\text { score }\end{array}$ & $\begin{array}{c}\text { Predation } \\
\text { score }\end{array}$ & $\begin{array}{c}\text { Total risk } \\
\text { score }\end{array}$ \\
\hline \multicolumn{5}{|l|}{ Very high risk } \\
\hline Adalia bipunctata & 3 & 3 & 3 & 18 \\
\hline Adalia decempunctata & 3 & 3 & 3 & 18 \\
\hline Calvia decemguttata & 3 & 3 & 3 & 18 \\
\hline Oenopia conglobata & 3 & 3 & 3 & 18 \\
\hline \multicolumn{5}{|l|}{ High risk } \\
\hline Myzia oblongoguttata* & 3 & 3 & 2 & 15 \\
\hline Coccinella quinquepunctata & 2 & 3 & 3 & 12 \\
\hline Coccinella undecimpunctata & 2 & 3 & 3 & 12 \\
\hline Harmonia quadripunctata & 2 & 3 & 3 & 12 \\
\hline \multicolumn{5}{|l|}{ Medium risk } \\
\hline Anisosticta novemdecimpunctata* & 2 & 3 & 2 & 10 \\
\hline Coccinella magnifica* & 2 & 3 & 2 & 10 \\
\hline Coccinella septempunctata & 2 & 3 & 2 & 10 \\
\hline Coccinula quatuordecimpunctata* & 2 & 3 & 2 & 10 \\
\hline Myrrha octodecimguttata* & 2 & 3 & 2 & 10 \\
\hline Platynaspis luteorubra & 2 & 3 & 2 & 10 \\
\hline Anatis ocellata & 2 & 3 & 1 & 8 \\
\hline Calvia quatuordecimguttata & 2 & 3 & 1 & 8 \\
\hline Chilocorus bipustulatus* & 2 & 2 & 2 & 8 \\
\hline Exochomus nigromaculatus* & 2 & 2 & 2 & 8 \\
\hline Exochomus quadripustulatus* & 2 & 2 & 2 & 8 \\
\hline \multicolumn{5}{|l|}{ Low Risk } \\
\hline Cynegetis impunctata* & 2 & 1 & 2 & 6 \\
\hline Halyzia sedecimguttata* & 2 & 1 & 2 & 6 \\
\hline Hippodamia variegata & 1 & 3 & 3 & 6 \\
\hline Aphidecta obliterata & 1 & 2 & 3 & 5 \\
\hline Propylea quattuordecimpunctata & 1 & 3 & 2 & 5 \\
\hline Chilocorus renipustulatus $*$ & 1 & 2 & 2 & 4 \\
\hline Coccinella hieroglyphica* & 1 & 2 & 2 & 4 \\
\hline Henosepilachna argus* & 1 & 1 & 2 & 3 \\
\hline Psyllobora vigintiduopunctata* & 1 & 1 & 2 & 3 \\
\hline Subcoccinella vigintiquatuorpunctata* & 1 & 1 & 2 & 3 \\
\hline Tytthaspis sedecimpunctata* & 1 & 1 & 2 & 3 \\
\hline
\end{tabular}

*Species that were not experimentally assessed for the impact of intra-guild predation. 